\title{
CAN HUMAN RESOURCES INDUCE SUSTAINABILITY IN BUSINESS? MODELING, TESTING AND CORRELATING HR INDEX AND COMPANY'S BUSINESS RESULTS ${ }^{1}$
}

\author{
Jovan Zubović2 ${ }^{2}$ Marko Jeločnik ${ }^{3}$,Jonel Subić ${ }^{4}$
}

\begin{abstract}
In this paper the authors analyze the impact of the composite human resource index on sustainable growth in a specific business sector in a transition country. Sustainability of country's economy is growingly relying on the knowledge economy which has been implemented in strategies of sustainable development throughout Europe. The knowledge economy is mostly based on human resources and the way they are organized and managed in the companies actively operating in competitive markets. In order to confirm importance of the human resources (HR) index, results were tested by means of modeling, measuring and correlating the HR index with business results at micro level. The tests were conducted on the data from the survey in Serbian meat processing industry. The results were then compared with the results from the survey conducted in a financial industry. Moreover, a model was made that could be applicable in all countries that do not have available official statistic data on the level of investments in human resources. The focus was on determining the correlation direction, and hence creating a research model applicable in all business sectors. It has been found that a significant one-way correlation exists between business performance and increased HR index. In that way it has been confirmed that in Serbian economy that has recorded global decrease during transition, certain business sectors, and especially companies with high levels of investments in improving its HR index record above average and sustainable growth.
\end{abstract}

Key words: Investments, HR index, Correlation, Modeling.

JEL: $Q 13, M 54$

1 This paper is prepared as a result of participation in the projects 179001, 179015 and 46006 of the Ministry of Education and Science of the Republic of Serbia.

2 Jovan Zubović, Ph.D., Research Associate, Institute of Economic Sciences, Zmaj Jovina Street no. 12, 11000 Belgrade, Serbia, Phone: +381 112623 055, E-mail: jovan.zubovic@ien.bg.ac.rs

3 Marko Jeločnik, M.A., Research Assistant, Institute of Agricultural Economics, Volgina Street no. 15, 11060 Belgrade, Serbia, Phone: 381116972 852, E-mail: marko_j@iep.bg.ac.rs

4 Jonel Subić, Ph.D., Senior Research Associate, Institute of Agricultural Economics, Volgina Street no. 15, 11060 Belgrade, Serbia, Phone: 381116972 858, E-mail:, jonel s@iep.bg.ac.rs

EP 2015 (62) 2 (399-420) 


\section{Introduction}

Importance of human resources has been changing significantly through history. Sustainable economic growth was initially based on the dominant role of natural factors and physical labor. During the industrial expansion, the most important factors of production were real and financial capital. Due to the technological developments achieved in the twentieth century the so called "weightless economy" became dominant factor for generating value added. Growth in importance of such an economy today is not visible only in the service sector. Modern agriculture and industry increasingly depend on knowledge and skills. Technological development has made manual labor, material capital, as well as natural and financial resources gradually lose on their importance. In a society where the economy is based on knowledge as a backbone of comparative advantage, a key factor of the production is a group of intangible factors. They include knowledge, skills and work culture, which are gaining greater market value over time (Zubovic et al., 2008). Growing impact of knowledge-based economy during last two decades has significantly fostered the importance of human resources, both on micro and macro level. According to Awang et al. (2010) "the competitiveness of nation and companies in the knowledge-based economy today lies more on their knowledge and intellectual capital than on other resources".

The concept of sustainable development based on new growth theory which relies on the applied knowledge originates from the nineties of the $20^{\text {th }}$ century. According to that concept the knowledge can be more or less economically efficient. In the knowledge based economy, textbook knowledge the is not the basis of success, but the ability to solve problems, to generate and implement innovation and to cooperate with others. The knowledge economy became a popular topic for research worldwide. Several studies indicate its significance and serve as a basis for providing national strategies for promotion of sustainable growth. The knowledge economy has proven to be the basis for sustainable development of European Union since the Lisbon Agenda. In the knowledge based economies human resources are viewed as one of the generators of success on both micro and macro level. (De la Fuente, Ciccone, 2002).

In this paper we are striving to expand and extend research on this issue by introducing new element in the research - analysis of HR practices impact on business results by industry sectors. Empirically we focus on meat processing industry in which we expect to confirm that higher levels of HR practices measured by HR index result in improved business indicators achieved in the following years. By means of an analysis in the meat processing industry in Serbia, the research focused on evaluation of relations between (positive) business results and investments in human resources. In the second part we give review of some theoretical arguments regarding the paper hypothesis. The third part presents the facts about the sustainability of Serbian industry in general. The fourth part of the paper presents the methodology used, while in the fifth part we deliver the results and discussion of the results from the empirical survey. The paper closes with the conclusion on the results achieved. 


\section{Theoretical Background}

According to Stacey (2001) human capital and intangible assets create intellectual capital. Both can be measured by valid quantitative methods. In such a way we can derive an index of intellectual capital, which includes not only the number of hours spent in training, or the number of patents made, but the extent of such utilization capacity of the company in the business process. This approach allows the computation of accurate indicators of potential business growth in the future.

As noted above, in accordance with De la Fuente and Ciccone (2002) human resources and human capital are viewed as the core generators of success both on micro and macro level in the knowledge based economies. The concept of Human Capital Index has been applied on macro level in the case of Pakistan, Bulgaria and Colombia in order to confirm importance of human resources in developing economies (Mubarik et al., 2014; Ene, 2012; Montoya, 2013).

Some authors have confirmed relationship between specific elements of HR practices with positive business results, for example in Darwish et al. (2013) where the authors found that training have strong positive impact on assets and return on equity.

Focusing on the micro level, one of the first models named the "Human Capital Index HCI" was created by Watson Wyatt Worldwide Research (2012). The HCI has emerged as a result of the research practices of human resources in 750 organizations in the USA and Europe. In the analysis, Watson Wyatt Worldwide Research allocated 47\% of the market value growth in analyzed companies to intangible components of human resources which include system of rewards and responsibilities, collegial and flexible workplace, excellent policy of recruitment and retention, integrity of communications and focused HR technology. The study shows that firms with low level of HCI have achieved an average $21 \%$ return on investment, firms with an average HCI have made 39\% return, while firms with a high $\mathrm{HCI}$ achieved $64 \%$ on return.

Growing number of companies are aware that their sustainable growth in the competitive market is closely related to the level of human capital of their employees. What is paradoxical is that while the organizations are aware of the importance of human resources, corporate investments in human resources (such as basic skills, quality of training and lifelong education) are rarely evaluated since they are not familiar with the benefit of such investments. That is especially the case in some developing countries of Eastern Europe and Russia, where the roots of the planned economy and Soviet-era heritage in human resource management are still influential (Denisova Schmidt, 2011). It is common for accounting/ finance departments in organizations to thoroughly monitor and evaluate investment in assets, research \& development, while investment in human resources is rarely found in the financial statements. No matter how good the external environment is, according to Done and Domazet (2011) it is very important to focus on people with their knowledge and skills.

Several studies (Bassi, McMurrrer, 2007; Dearden et al., 2002; Greer, 2006; Hanson et al., 2004; Chasovskaya, 2010; Tkachenko, Ardichvili, 2013; Birch et al., 2010; Zubović, 
Domazet, 2013) have shown that strategically planned investments in human capital continuously create higher skilled, more innovative, productive and loyal employees, hence providing the organization with a sustainable competitive advantage over their less progressive competitors. Investments in human capital generate both short term and long term benefits that will provide more skilled and productive employees, as well as improve their loyalty and ethics. For example according to Chasovskaya (2010), the loyalty of employees is one of the most important factors that improve company's efficiency, since such employees produce goods of better quality, learn new technologies quicker, and are more tolerant to changes. Tkachenko and Ardichvili (2013) suggest that training can yield to both individual- and organizational-level benefits and generate substantial gains in productivity, profitability, and stock performance. Both loyalty and training of an employee are responsibility of HR departments which are a component of $\mathrm{HR}$ index, explained later in the text. Greer (2006) emphasizes that human resources should be viewed as an investment perspective. According to Bassi and McMurrer (1999), business environment with no sufficient information in the investments in human capital and not adequately evaluated leads to at least three outcomes: some of the investments in human resources are ineffective; it is difficult to distinguish good from poor investments; due to inability to evaluate the effects of investments in human resources financial markets neglect the importance of such investments. At the micro level some studies have evaluated the effectiveness of human capital investments in a specific company in order to confirm its feasibility (Kwon, Rupp, 2013).

Information on the investments in human resources is often not available; therefore it is difficult to evaluate their effectiveness. That makes investors resistant to appreciate such investments, even if they are profitable, especially in the long run. Despite such resistance, application of improved scientific methodology in this field in recent decades has brought some positive impact. Findings in this paper will certainly be added to knowledge database which should lead to higher appreciation of investments in HR.

Due to a fact that data about the level of investment in human resources and the quality of HR departments in companies operating in Serbia is not available, the aim of this paper is to provide alternative method of obtaining such information. It includes comparison of the results and correlation tests among individual variables composing the Index of Human Resources (HR Index). For that purpose there has been used a questionnaire to generate nine variables that are correlated with company business results (such as change in assets value, profitability, ROA and changes in employment). Such an approach provides more in-depth results than the research conducted by Cranet (2008). Novelty is based on an assumption that the effectiveness of investments in development of human capital differs among business sectors in the one country's economy. To a certain extent Theriou and Chatzoglou (2014) have disaggregated economy by applying three sectors' division and identified that manufacturing firms with good HR practices tend to achieve higher performance indicators. Similarly Katou and Budgwar (2012) have conducted a research in service sector companies and proved that companies pursuing improved HR practices achieve superior organization performance. In our paper the results achieved from the meat processing industry are compared with the survey conducted in the financial sector (Zubović 
et al., 2011), which opened the way for continued research in other sectors that needs to be pursued in the future. However it was necessary to conduct a research in a more labour oriented industry, in order to test the assumption that there is significant difference in HR Index among different sectors.

\section{Legal and Empirical facts on Sustainability of Serbian Economy}

Despite the fact that transition in Serbia was officially initiated in 2000, only in 2007 there was adopted the final version of the National Strategy for Sustainable Development for the period 2008-2017 (Government of Serbia, 2008). The strategy, among others, comprises the analysis of the strengths and opportunities on the one hand and weaknesses and threats on the other hand for sustainable development of Serbian economy until year 2017. It further states that sustainable economic development should enable continuous long term growth that will be based primarily on knowledge, information, people, education and the quality of the relationship between people and institutions rather than on the excessive use of natural resources. Apparently such an economy requires high levels of human capital, human resources and their organization in the companies (Government of Serbia, 2008). Achieving sustainable development in Serbia will be based on adaptation and application of the principles prevailing in the European Union, which rely on increased competitiveness based on knowledge, innovation and entrepreneurship.

Among the Strategy's advantages there have been noted skilled labor force and the growth of the private sector. Weaknesses that are observed are related to slow privatization process, insufficient Greenfield investments, continued brain-drain, very low share of expenditure on education and science, and adverse socio-economic situation of young people. The opportunities that are observed in the Strategy include, among others: the completion of the privatization process, growing reliance on knowledge based economy and increasing public-private partnerships, while threats to successful sustainable development are the rise of unemployment, poverty, debt and slow economic growth, unfavorable demographic trends, and the possible absence of political will to implement legal reforms. Having a look on the Strategy from the perspective of nearly ten years one can observe that mostly all elements of the SWOT have been properly detected. Strengths shown in the form of skilled labour force accompanied with growing importance of knowledge based economy have proved to be successful factors needed for sustainable growth. According to Nikolić and Zubović (2013) as a result of harsh structural changes in transition period there have been recorded poor economic results in Serbian economy at the global level. However, in 2012 meat processing industry recorded above average results and achieved 17\% growth as compared to 2000 .

Serbian economy currently functions on the basis of generally unfavorable economic structure, given the natural and financial resources, technology and labour. All of these resources are relatively scarce. The limitation partly stems from the relatively weak natural, technological and financial basis. Serbia with less than eight million people and a gross domestic product of just above $€ 30$ billion does not represent a significant 
market with large economic potential, observed on global or European level. Despite such poor data from the general environment, the use of appropriate development strategies could significantly improve relatively poor position compared to the reference countries in transition, especially those from Southeastern Europe. The progress in the next phase of development of the Serbian society, state and economy must not be short termed and unpredictable. It is necessary to provide conditions for the sustainable development of the economy based on knowledge which will lead to an increase in the group of key economic indicators such as GDP growth, employment, foreign trade, competitiveness, exports, investment and standards of the population. Subic and associates (2013) confirmed that Serbian agro-food industry achieved sustainable growth and that market economy and market principles certainly had an impact on that sector. For this reason, in this paper, the authors have attempted to generate so-called HR Index (HRI), which should simplify the evaluation of all these elements and confirm their impact on the sustainable growth of companies operating in the meat processing sector that is a significant component of the agro-food industry.

\section{Methodology}

In order to confirm the objective of the paper the research has been conducted in the Serbian meat processing industry. The methodology used in this study is an improvement of Zubović et al. (2011), Cranet (2008) and Watson Wyatt Worldwide Research (2012) models. Watson Wyatt Worldwide Research model examines relationship between the effective use of organization's human capital and the creation of higher returns. Cranet (2008) gives metadata on research conducted in 39 countries using the standardized questionnaire. Results obtained from the survey are used for comparison of data from a sample with the average of all companies operating in the same economic sector. Comparisons are made on productivity, level of innovation, quality of service, profitability and stock prices in the stock market.

Some authors (for example Griliches, 1997) present research and detailed methodology of meta-data on 6.685 companies from 26 countries. However these researches have been conducted on the sample of all companies in the target country regardless of the business sector. In this paper we assume that HR index and correlations significantly differ among business sectors, hence resulting in the need to divide research results by business sectors. Zubović et al. (2011) have tested two-way correlations between HR Index and company business results in the financial sector. Meat processing industry is a reliable business sector for comparison with the financial sector for some similarities and differences among them. As the most important similarity we want to emphasize the fact that small number of companies in both sectors has a relatively significant share in total value of assets. Among the differences, the following could be underlined as the most important: technical and technological practices conducted on daily basis in business activities, having in mind that one sector is labour-oriented and other is service-oriented; structure of employees according to level of education, required abilities and skills (higher level of education is more presented in financial sector); share of foreign capital in the sectors is significantly higher in financial 
sector. Hence comparison of results in financial sector with those obtained in this paper would certainly bring about important implications.

A survey containing 24 questions, divided into nine groups of questions was used to generate HR Index. Scores obtained in nine groups will be used as nine observed variables (Variables) in econometric testing. Results from the competed questionnaires were coded in the following way:

- Total of 24 questions are grouped in nine groups of questions to compose nine variables (column 1, Table 1);

- Responses to each question are assigned maximum values of $0.5,1$ or 2 , depending on the importance of the question;

- Different number of questions is assigned to 9 variables (columns 2-4, Table 1). The total of ten questions are assigned maximum value 0.5 ; thirteen questions maximum value 1 and one question maximum value of 2 points. This distribution is an adjustment made to Cranet (2008) which used 55 questions, and Zubovic et al. (2011) which used the same number of questions related to HR practices but included some other related to general business.

- Variable's maximum values range between 1 and 5. Variable's maximum value is shown in column 5, Table 1 (Letter C represents Column);

- Nine variables are used to compose a HR index (last row, Table 1). HR Index represents the sum of individual values of the variables, thus its value can range between 0 and 20 .

Table 1. Distribution and values of observed variables composing the HR Index

\begin{tabular}{|l|c|c|c|c|}
\hline \multirow{2}{*}{\multicolumn{1}{|c|}{ Observed variables }} & \multicolumn{3}{c|}{$\begin{array}{c}\text { Number of questions } \\
\text { composing a variable }\end{array}$} & $\begin{array}{c}\text { Maximum value } \\
\text { (C2 } * \mathbf{0 . 5}+\mathbf{C} 3 * \mathbf{1}+\mathbf{C 4} \text { *2) }\end{array}$ \\
\cline { 2 - 4 } & $\begin{array}{c}\mathbf{0 . 5} \text { points } \\
\text { (C2) }\end{array}$ & $\begin{array}{c}\mathbf{1} \text { point } \\
\text { (C3) }\end{array}$ & $\begin{array}{c}\mathbf{2} \text { points } \\
\text { (C4) }\end{array}$ & \\
\hline 1. Company size & 0 & 1 & 0 & 1 \\
\hline 2. Training policy & 0 & 4 & 0 & 4 \\
\hline 3. Evaluation of training needs & 0 & 3 & 0 & 3 \\
\hline 4. Quality of HR department & 8 & 1 & 0 & 5 \\
\hline 5. Internal recruiting policy & 0 & 0 & 1 & 2 \\
\hline 6. Employees age & 0 & 1 & 0 & 1 \\
\hline 7. Role and strength of unions & 2 & 1 & 0 & 2 \\
\hline 8. Participation of manual labour & 0 & 1 & 0 & 1 \\
\hline 9. Participation of graduated labour & 0 & 1 & 0 & 1 \\
\hline Total HR Index & $\mathbf{1 0}$ & $\mathbf{1 3}$ & $\mathbf{1}$ & $\mathbf{2 0}$ \\
\hline
\end{tabular}

Source: Zubović et al., 2012.

The research population used in this paper represents all companies belonging to Meat processing industry (MPI) in Serbia. A survey on a sample of companies belonging to the population in year 2010 has been conducted for composing the HR Index. The same sample was used in correlation testing of variables and Crombach's alpha test. Further on, the business results of sampled companies for the period 2009-2011 have been used 
for final correlation purposes.

A survey in the form of the questionnaire was completed by ten enterprises belonging to the population. Randomness of the sample was achieved by distributing the questionnaires to all 54 companies that belong to large/medium companies according to their number of employees, as well as to 50 (out of total 372) small companies. Questionnaires were completed by eight large/medium and two small companies. Despite the small response rate, the size of the sample is satisfactory because according to official statistical data the sample covers over $15 \%$ of the total population by three indicators (number of employees, assets values and turnover). The value of assets of the sampled companies create around $21 \%$ share of total assets of the population in 2010 , over $23 \%$ of total turnover and employ $20 \%$ of all labour force (see Table 2 ). Moreover, we have to note that nearly $90 \%$ of companies in population belong to category of small companies which according to official statistical data generate less than $10 \%$ in total employment and assets values. Data gathered from the survey was accompanied with official financial statements obtained from the Serbian Business Registers Agency.

Data collected from the survey were used for correlation tests in order to confirm existence of correlation between HR index and its components with business results. Correlation was tested using Pearson correlation and Spearman's correlation coefficient (SCC), indicating the degree of variability in quantitative relations of two random variables. Correlation coefficients were calculated using a standard software package for statistical analysis of SPSS data for two different correlations test. Spearman coefficient is more applicable in the absence of normal distribution of data and a small sample size of less than 30, so we will predominantly focus on these results. Even though Pearson coefficient might not be appropriate for tests on small sample, we have included it in order to verify the quality of the results. Since the results in both tests showed nearly the same values we recommend for any future analysis not to use both tests, but to rely solely on SCC. Finally the regression analysis has been introduced with a goal to confirm the achieved results.

\section{Results and Discussion}

\section{HR Index}

According to data shown in Annex (Table 12), companies from this sector participated in 2010 with $6.4 \%$ in total Agriculture and Agro-food industry, employing around $11.5 \%$ of total workers and generating around $7.6 \%$ of total turnover within total agriculture and agro-food industry (see Figures 1-3). 
Figure 1. Number of companies in agriculture and agro-food industry in Serbia (2009/2010)

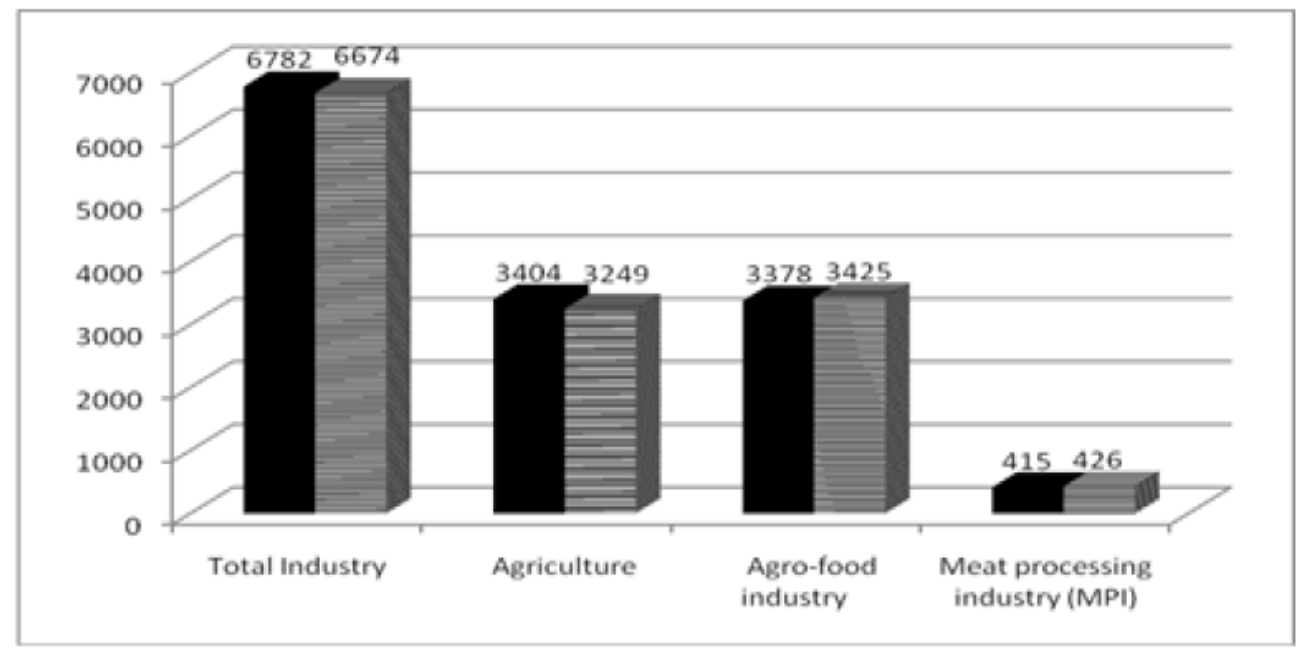

Source: SBRS, 2012.

Note: Black bars represent year 2009.

Figure 2. Number of employees in agriculture and agro-food industry in Serbia (2009/2010)

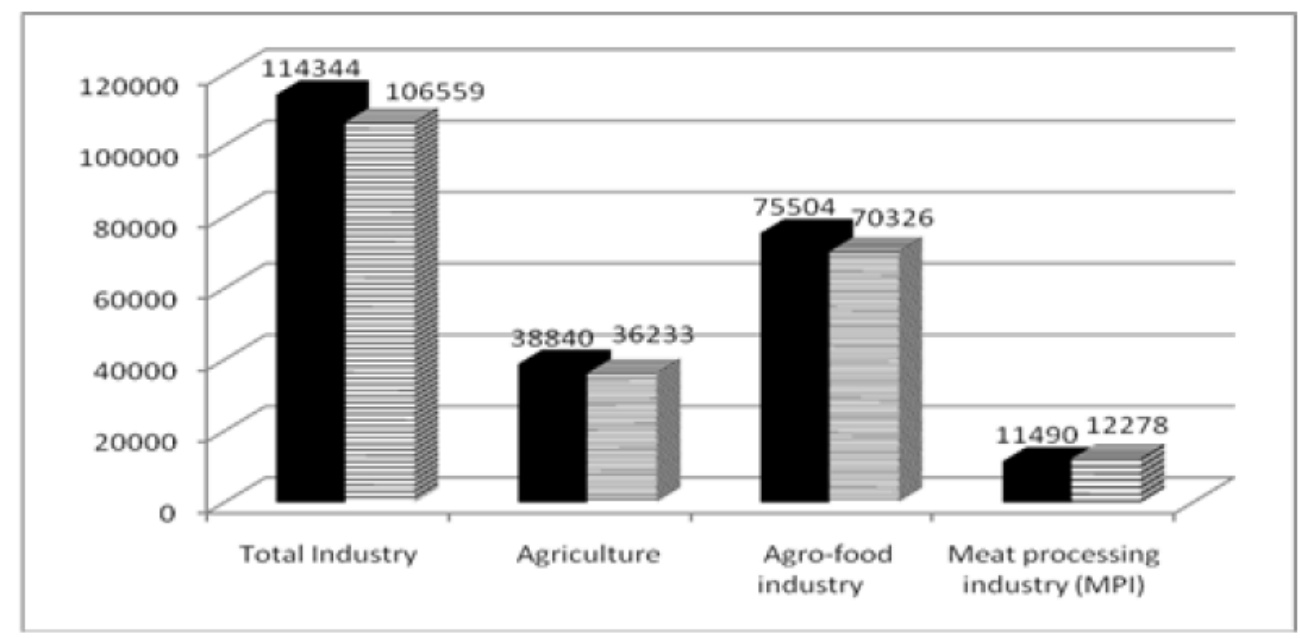

Source: SBRS, 2012.

Note: Black bars represent year 2009. 
Figure 3. Turnover in agriculture and agro-food industry in Serbia (2009/2010) (in € mil.)

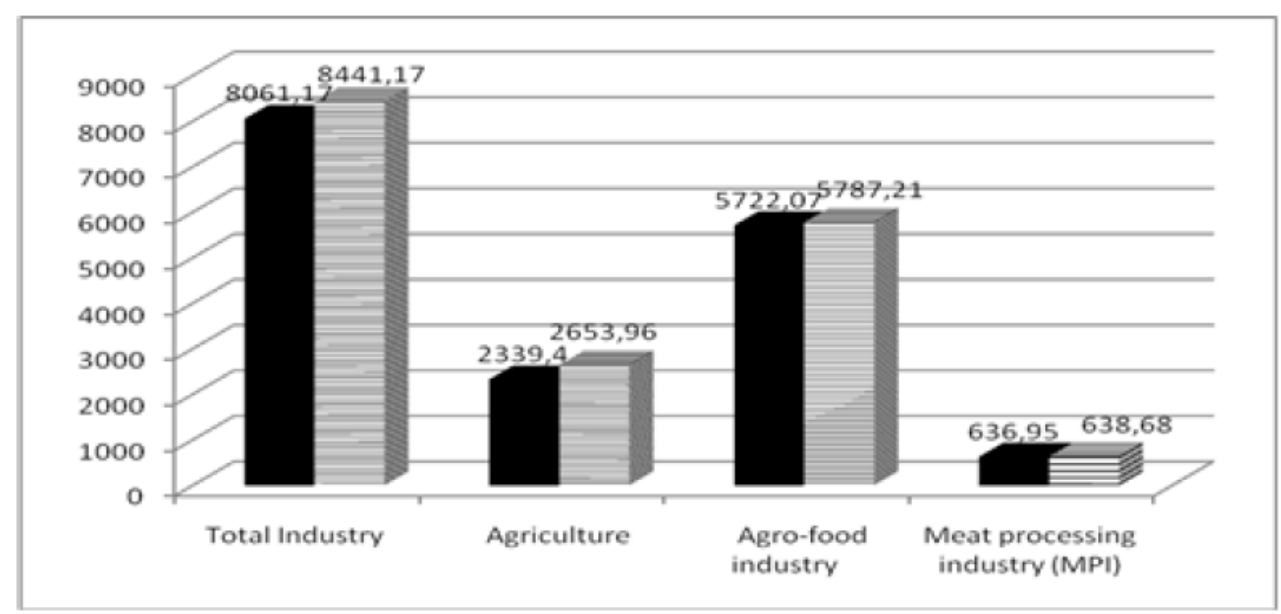

Source: SBRS, 2012.

Note: Black bars represent year 2009.

Using the model of HR Index presented in Table 1, HR Indices have been calculated for sampled companies (Table 2). Bottom row in Table 2 shows data from the research conducted by Zubović et al. (2011) in Serbian financial industry. Therefore we are able to compare results in two different industries in Serbia in the same points of time (last 2 rows, Table 2).

Table 2. Survey results and values of HR Indices

\begin{tabular}{|c|c|c|c|c|c|c|c|c|c|c|}
\hline Variable & $\begin{array}{c}\text { 1. Firm } \\
\text { size }\end{array}$ & $\begin{array}{c}\mathbf{2 .} \\
\text { Training } \\
\text { policy }\end{array}$ & $\begin{array}{c}\mathbf{3 .} \\
\text { Training } \\
\text { needs }\end{array}$ & $\begin{array}{c}\text { 4. Quality } \\
\text { of HR } \\
\text { Dept. }\end{array}$ & $\begin{array}{c}\mathbf{5 .} \\
\text { Recru- } \\
\text { iting }\end{array}$ & 6. Age & 7. Unions & $\begin{array}{c}\text { 8. Manual } \\
\text { labour }\end{array}$ & $\begin{array}{c}\text { 9.Gradu- } \\
\text { ated }\end{array}$ & $\begin{array}{c}\text { 10. HR } \\
\text { Index }\end{array}$ \\
\hline $\begin{array}{c}\text { Firm } \\
\text { score }\end{array}$ & $\mathbf{1}$ & $\mathbf{4}$ & $\mathbf{3}$ & $\mathbf{5}$ & $\mathbf{2}$ & $\mathbf{1}$ & $\mathbf{2}$ & $\mathbf{1}$ & $\mathbf{1}$ & $\mathbf{2 0}$ \\
\hline $\mathbf{A}$ & 0,8 & 0 & 0 & 0 & 2 & 0.8 & 0 & 0.2 & 0.1 & 3.9 \\
\hline B & 1 & 2.9 & 3 & 4.3 & 2 & 0.5 & 1 & 0.7 & 0.1 & 15.5 \\
\hline C & 1 & 1.1 & 0.5 & 1 & 0 & 0.7 & 1.2 & 0.2 & 0.1 & 5.8 \\
\hline D & 0.8 & 0.2 & 0 & 0.3 & 0.2 & 1 & 0 & 0.2 & 0.1 & 2.8 \\
\hline E & 0.2 & 2.5 & 2.8 & 4.5 & 2 & 0.8 & 1.3 & 0.2 & 0.1 & 14.4 \\
\hline F & 0.8 & 1 & 0.3 & 0 & 0.5 & 0.9 & 0.3 & 0.4 & 0.2 & 4.4 \\
\hline G & 0.5 & 1.4 & 0 & 2.2 & 2 & 0.4 & 1.2 & 0.3 & 0.1 & 8.1 \\
\hline H & 1 & 0.7 & 1 & 1.1 & 1 & 0.5 & 1 & 0.3 & 0.1 & 6.7 \\
\hline I & 1 & 1.2 & 2 & 3.5 & 0.2 & 0.6 & 1.6 & 0.2 & 0.2 & 10.5 \\
\hline J & 0.2 & 0.6 & 0.7 & 1.9 & 0 & 0.5 & 0.3 & 0.2 & 0.2 & 4.6 \\
\hline Average & $\mathbf{0 . 7}$ & $\mathbf{1 . 2}$ & $\mathbf{1 . 0}$ & $\mathbf{1 . 9}$ & $\mathbf{1 . 0}$ & $\mathbf{0 . 7}$ & $\mathbf{0 . 8}$ & $\mathbf{0 . 3}$ & $\mathbf{0 . 1}$ & $\mathbf{7 . 7}$ \\
\hline FIN* & $\mathbf{0 . 9}$ & $\mathbf{2 . 6}$ & $\mathbf{1 . 7}$ & $\mathbf{3 . 2}$ & $\mathbf{1 . 5}$ & $\mathbf{0 . 8}$ & $\mathbf{0 . 7}$ & $\mathbf{0 . 9}$ & $\mathbf{0 . 4}$ & $\mathbf{1 2 . 6}$ \\
\hline * Data gathered from Zubovic et al. (2011) & & & & & & \\
\hline
\end{tabular}

Source: Authors calculation according to Zubović et al., 2011; Zubović et al., 2012. 
Column 1 shows the results related to company size. Column 2 contains scores related to HR procedures in the company (named Training policy) - existence of normative acts for relationship with employees; amounts invested in training and development; time spent for training and the process of career development. Column 3 lists the results from the set of questions analyzing the quality of the system for proper definition of training needs. The fourth column indicates the highest number of index points, and it is linked to the quality of human resources department in the company. There are major differences among companies that will significantly affect the subsequent correlation analysis. In the following column the questions regarding internal recruitment in the company are grouped. Column 6 shows the percentage of employees younger than 45 years of age. Questions related to labor unions are shown in column 7. The variable represented as manual workers in column 8 , in fact, shows the percentage of employees who work as manual labour. The last column shows the synthesized HR index.

Values of HR Index range between 2.9 and 15.5 points, with an average score of 7.7 points (out of maximum 20 points). This range of HR index values, with large variations, provides good basis for application of Spearman correlation coefficients, as it will be discussed later.

The last two rows in Table 2 indicate average results of the surveys conducted in two different business sectors, namely meat processing industry and financial sector. As one of the purposes of this study was to show a significant difference in HR Index among different sectors, the results show that financial sector achieved has much higher scores in all groups of questions, except for unions. Therefore, our hypothesis that research needs to be conducted independently in different business sectors is proven.

\section{Index Correlation Testing}

The survey results are used in correlation tests. In the first test we have used both Pearson and Spearman coefficients. The goal of the first test is to verify that there is no full correlation among variables. In that way it can be assured that results obtained could be used in regression analysis that can be conducted in the future after completion of research in several business sectors. A test on correlation was conducted between nine variables used to create HR Index (Table 3). We have set the hypotheses as follows:

The Null hypothesis $H_{0}$ is: There is no full correlation between any of the variables which comprise the HR Index.

The Alterative hypothesis $H_{1}$ is: There is a full correlation between some of the variables which comprise the HR Index. 
Table 3. Correlation between nine variables which create the HR Index

\begin{tabular}{|c|c|c|c|c|c|c|c|c|c|}
\hline \multicolumn{2}{|c|}{ Variable } & \multirow{2}{*}{\begin{tabular}{r|}
$\begin{array}{c}\text { Training } \\
\text { policy }\end{array}$ \\
,- 108
\end{tabular}} & \multirow{2}{*}{\begin{tabular}{r|}
$\begin{array}{c}\text { Training } \\
\text { needs }\end{array}$ \\
,- 024
\end{tabular}} & \multirow{2}{*}{$\begin{array}{r}\begin{array}{c}\text { Quality of } \\
\text { HR Dept. }\end{array} \\
-, 244 \\
\end{array}$} & \multirow{2}{*}{\begin{tabular}{r|} 
Recruiting \\
,- 177 \\
\end{tabular}} & \multirow{2}{*}{\begin{tabular}{l|} 
Age \\
, 050 \\
\end{tabular}} & \multirow{2}{*}{\begin{tabular}{r|} 
Unions \\
, 115 \\
\end{tabular}} & \multirow{2}{*}{$\begin{array}{r}\begin{array}{l}\text { Manual } \\
\text { labour }\end{array} \\
, 333 \\
\end{array}$} & \multirow{2}{*}{$\begin{array}{r}\begin{array}{c}\text { Graduate } \\
\text { d }\end{array} \\
-, 137 \\
\end{array}$} \\
\hline \multirow{4}{*}{$\begin{array}{l}\text { Company } \\
\text { size }\end{array}$} & $\mathrm{PC}^{1}$ & & & & & & & & \\
\hline & \begin{tabular}{|l|} 
Sig. (2-tailed) \\
\end{tabular} &, 766 & ,948 & ,497 & ,624 &, 890 & ,752 & ,347 &, 707 \\
\hline & $\mathrm{SCC}^{2}$ & , 114 & 270 &,- 083 &,- 149 &,- 087 & , 174 & 270 &,- 120 \\
\hline & Sig. (2-tailed) &, 753 &, 450 &, 820 &, 682 &, 811 &, 631 &, 451 &, 742 \\
\hline \multirow{4}{*}{$\begin{array}{l}\text { Training } \\
\text { policy }\end{array}$} & PC & & $.843^{i=1}$ & $.860^{* \pi}$ & 472 &,- 313 & $.635^{*}$ & 614 &,- 169 \\
\hline & Sig. (2-tailed) & &, 002 &, 001 &, 168 &, 379 &, 049 &, 059 &, 641 \\
\hline & SCC & & $.644^{2}$ & $809^{* \pi}$ & 371 &,- 400 & $.773^{* \pi *}$ & ,418 &,- 114 \\
\hline & Sig. (2-tailed) & &, 044 &, 005 & ,291 &, 252 &, 009 & 229 &, 754 \\
\hline \multirow{4}{*}{$\begin{array}{l}\text { Training } \\
\text { needs }\end{array}$} & $\mathrm{PC}$ & & & $900^{*=1}$ & 310 &,- 235 & ,592 & ,441 &,- 018 \\
\hline & Sig. (2-tailed) & & &, 000 & ,384 &, 513 & 071 & 202 &, 961 \\
\hline & SCC & & &, $757^{*}$ &, 083 &,- 287 &, 565 &, 180 &, 115 \\
\hline & Sig. (2-tailed) & & &, 011 &, 820 &, 422 &, 089 & ,618 &, 751 \\
\hline \multirow{4}{*}{$\begin{array}{l}\text { Quality } \\
\text { of HR } \\
\text { department }\end{array}$} & $\mathrm{PC}$ & & & & ,372 &,- 443 & $.712^{*}$ & ,321 &,- 032 \\
\hline & Sig. (2-tailed) & & & & ,289 &, 200 &, 021 & ,367 &, 930 \\
\hline & $\mathrm{SCC}$ & & & &, 281 &,- 515 & $.738^{*}$ &, 065 &,- 076 \\
\hline & Sig. (2-tailed) & & & &, 432 &, 127 &, 015 & ,858 &, 834 \\
\hline \multirow{4}{*}{ Recruiting } & PC & & & & &,- 220 &, 135 & 388 &,- 571 \\
\hline & Sig. (2-tailed) & & & & &, 541 &, 710 &, 268 &, 085 \\
\hline & SCC & & & & &,- 153 & ,057 & ,438 &,- 513 \\
\hline & Sig. (2-tailed) & & & & &, 672 &, 875 & 206 &, 130 \\
\hline \multirow{4}{*}{ Age } & PC & & & & & &,- 525 &,- 289 &,- 011 \\
\hline & Sig. (2-tailed) & & & & & &, 119 &, 419 &, 975 \\
\hline & $\mathrm{SCC}$ & & & & & &,- 389 &,- 348 &, 039 \\
\hline & Sig. (2-tailed) & & & & & &, 266 &, 324 & ,916 \\
\hline \multirow{4}{*}{ Unions } & $\mathrm{PC}$ & & & & & & &, 082 &,- 067 \\
\hline & Sig. (2-tailed) & & & & & & & 821 &, 854 \\
\hline & $\mathrm{SCC}$ & & & & & & &,- 042 &, 038 \\
\hline & Sig. (2-tailed) & & & & & & & ,909 & ,916 \\
\hline \multirow{3}{*}{$\begin{array}{l}\text { Manual } \\
\text { labour }\end{array}$} & \begin{tabular}{|l} 
PC \\
Sig. (2-tailed)
\end{tabular} & & & & & & & & $\begin{array}{r}-, 101 \\
, 781 \\
\end{array}$ \\
\hline & $\mathrm{SCC}$ & & & & & & & & $\begin{array}{r}-, 043 \\
906\end{array}$ \\
\hline & Sig. (2-tailed) & & & & & & & & \\
\hline \multicolumn{10}{|c|}{1 - Pearson correlation; } \\
\hline \multicolumn{10}{|c|}{2 - Spearman correlation coefficient; } \\
\hline \multicolumn{10}{|c|}{ *. Correlation is significant at the 0.05 level (2-tailed); } \\
\hline (1) & $\mathrm{n}$ is significan & at the 001 & 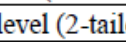 & & & & & & \\
\hline
\end{tabular}

Source: Authors calculation according to Zubović et al., 2012.

Based on data presented in Table 3 it is possible to conclude that there is not a large number of significant correlation relationships among the variables that make up the HR index, except for the variable Training Policy being significantly correlated to three out of eight other variables. However, since there is no full correlation we will not exclude this variable from further analysis. The variable Quality of HR department is also significantly correlated to three other variables, but only at 0,05 level. Hence, it will not be excluded from the second testing. 
In order to explore internal consistency of data used in Table 2 we have conducted Cronbach's alpha test $\left(\alpha_{\text {cronbach }}\right)$. Results are given in Table 4.

Table 4. Reliability Statistics of nine variables

\begin{tabular}{|r|r|r|}
\hline Cronbach's Alpha & Based on Standardized Items & N of Items \\
\hline 0,755 & 0,562 & 9 \\
\hline
\end{tabular}

Source: Authors calculation according to Zubović et al., 2012.

Value of $\alpha_{\text {cronbach }}$ of 0,775 assures acceptable reliability of the model. In this way, it has been confirmed that above named nine variables used for the HR index do not have a significant impact on one another and that there is no danger of not being able to distinguish the impact of each variable. We can conclude that the HR index is able to deliver sustainable and robust results in the next part of the research.

\section{Correlation of HR Index and business results}

Performance results have been included in the second correlation test. The focus was on the impact of changes in financial results in 2011/2010 and 2010/2009 to HR index (and components) in 2011. A new hypothesis is set as follows:

The Null hypothesis $\mathrm{H}_{2}$ is: There is a significant one way correlation of selected variables of business results on HR Index and its components in the selected companies.

The Alternative Hypothesis $H_{3}$ is: There is a significant two-way correlation of selected variables of business results and HR Index in the selected companies.

In this test we have included additional variables from the sample companies' financial statements (Table 5). This analysis was done using only Spearman coefficient, due to lack of normal distribution. The goal was to test correlation of selected business results with HR index and/or its components. In order to be able to test the set hypothesis we have included data on change in assets values for two time segments (2011 vs. 2010 and 2010 vs. 2009).

In Table 5 one may find some specific data on ten companies from the sample:

- Assets 11/10 - normalized values of change in company assets in 2011 compared to 2010 ; - i.e. we have reduced nominal values of change in assets by $8.7 \%$ (which equals to the growth rate in assets' values of all companies in population according to official statistics) in order to eliminate the impact of the exogenous factor of economic trends in the industry;

- Assets 10/09 - normalized values of change in company assets in 2010 compared to 2009 ; - i.e. we have reduced nominal values of change in assets by $8.4 \%$ (which equals to the growth rate in assets' values of all companies in population according to Table 3 ) in order to eliminate the impact of the exogenous factor of economic trends in the industry;

- ROA 10/09 - growth rate of ROA in 2010 as compared to 2009;

- Profit 10 - company profits in 2010 (in RSD million); 
Employees 10/09 - growth rate in the number of employees in 2010 as compared to 2009.

Table 5. Business results of sample companies for 2009 and 2010

\begin{tabular}{|c|c|c|c|c|c|}
\hline Company & Assets 11/10 & Assets 10/09 & ROA 10/09 & Profit 2010 & Employees 10/09 \\
\hline A & $-0,240$ & 0.212 & -0.167 & 2 & 0.176 \\
\hline B & 0,560 & 0.129 & -0.022 & 57 & -0.037 \\
\hline C & 0,147 & 0.251 & 0.075 & 3 & 0.103 \\
\hline D & 0,115 & 0.152 & -0.006 & 67 & 0.337 \\
\hline E & 0,934 & -0.207 & 0.616 & 85 & 0.197 \\
\hline F & $-0,220$ & 1.307 & -0.421 & 64 & 0.205 \\
\hline G & $-0,116$ & 0.041 & 0.059 & 1 & 0.000 \\
\hline H & 0,200 & -0.064 & -0.823 & -201 & -0.137 \\
\hline I & 0,135 & -0.086 & -0.091 & 17 & -0.032 \\
\hline J & $-0,185$ & -0.074 & -0.934 & 1 & -0.800 \\
\hline
\end{tabular}

Source: Authors calculations according to SBRS, 2012.

In the correlation test, we have analyzed the influence of business results of the selected companies to change in observed variables and in HR index in general on one hand (by observing the change in Assets values in the years preceding HRI), and the opposite direction, on the other hand (by observing the change in assets in the next year). We will do the same with business data from 2009, 2010 and 2011, and the variables creating HR Index from the mid 2011 (the time the survey was conducted). Using selected data from tables 2, 3 and 4 enables us to complete the second correlation analysis that will lead to most important conclusions (see Table 6) in order to test the hypothesis $\mathrm{H}_{2}$.

Data presented in Table 6 show some significant correlations. We can distinguish the following significant correlations:

1. Negative correlation of the Quality of HR department with the change in company assets (in the previous year 2010/2009);

2. Positive correlation of change in the HR Index, Quality of HR department, Training needs and Training policy with the change in company assets (in the next year 2011/2010);

3. Age of employees with the profit level;

4. Change in employment with the profit level;

5. Age of employees with change in employment.

At first, we should focus on correlations 3-5. We find them not to be very important, but still necessary to be explained. These three statistically significant correlations can be placed in a tripartite relationship. Since the variable Age, as noted in explanation of Table 2, represents the share of employees younger than 45 , it is to conclude that higher share of younger employees enables more job openings. That is because younger people, as a rule, have lower wages, which leads to higher profit margins for the owners. Since this industry is highly labor oriented, and skills needed are not very advanced, if profit margin is high, owners will employ more people in order to increase profit levels. 
Table 6. Correlation between selected variables and HRI with business results

\begin{tabular}{|c|c|c|c|c|c|c|}
\hline \multicolumn{2}{|c|}{ Variables } & \multirow{2}{*}{$\begin{array}{r}\text { Assets 10/09 } \\
280\end{array}$} & \multirow{2}{*}{$\begin{array}{r}\text { Assets 11/10 } \\
, 305\end{array}$} & \multirow{2}{*}{$\begin{array}{r}\text { ROA 10/09 } \\
-, 064\end{array}$} & \multirow{2}{*}{$\begin{array}{r}\text { Profit } 2010 \\
-, 124\end{array}$} & \multirow{2}{*}{$\begin{array}{l}\text { Employees } \\
\qquad 10 / 09 \\
-, 210\end{array}$} \\
\hline \multirow{3}{*}{ Company size } & SCC & & & & & \\
\hline & Sig. (2-tailed) &, 434 & ,391 &, 862 &, 732 &, 561 \\
\hline & $\mathrm{N}$ & 10 & 10 & 10 & 10 & 10 \\
\hline \multirow{3}{*}{$\begin{array}{l}\text { Training } \\
\text { policy }\end{array}$} & SCC &,- 345 & ,673" & ,539 & ,280 &,- 164 \\
\hline & Sig. (2-tailed) & ,328 &, 033 & , 108 & ,434 & ,651 \\
\hline & $\mathrm{N}$ & 10 & 10 & 10 & 10 & 10 \\
\hline \multirow{3}{*}{$\begin{array}{l}\text { Training } \\
\text { needs }\end{array}$} & SCC &,- 571 &, $767^{\text {kik }}$ & ,031 & ,191 &,- 472 \\
\hline & Sig. (2-tailed) &, 085 &, 010 & ,933 &, 598 &, 168 \\
\hline & $\mathrm{N}$ & 10 & 10 & 10 & 10 & 10 \\
\hline \multirow{3}{*}{$\begin{array}{l}\text { Quality of HR } \\
\text { Dept. }\end{array}$} & SCC &,$- 796^{k *}$ & ,729* & ,377 & ,134 &,- 419 \\
\hline & Sig. (2-tailed) &, 006 &, 017 & ,283 &, 712 & ,228 \\
\hline & $\mathrm{N}$ & 10 & 10 & 10 & 10 & 10 \\
\hline \multirow{3}{*}{ Recruiting } & SCC &,- 113 & ,164 & 245 & ,088 &, 120 \\
\hline & Sig. (2-tailed) &, 755 & ,651 & ,494 &, 808 &, 742 \\
\hline & $\mathrm{N}$ & 10 & 10 & 10 & 10 & 10 \\
\hline \multirow{3}{*}{ Age } & SCC & ,406 &,- 197 & , 166 &, $722^{*}$ &, $862^{\text {k* }}$ \\
\hline & Sig. (2-tailed) &, 244 & 586 & 646 & ,018 &, 001 \\
\hline & $\mathrm{N}$ & 10 & 10 & 10 & 10 & 10 \\
\hline \multirow{3}{*}{ Unions } & SCC &,- 558 & ,614 & 485 & ,049 &,- 245 \\
\hline & Sig. (2-tailed) &, 093 &, 059 &, 156 &, 893 &, 494 \\
\hline & $\mathrm{N}$ & 10 & 10 & 10 & 10 & 10 \\
\hline \multirow{3}{*}{ Manual labor } & SCC & ,274 & , 103 &,- 199 &,- 089 &,- 178 \\
\hline & Sig. (2-tailed) & ,443 & ,777 &, 582 &, 806 & ,622 \\
\hline & $\mathrm{N}$ & 10 & 10 & 10 & 10 & 10 \\
\hline \multirow{3}{*}{ Graduated } & $\mathrm{SCC}$ &,- 114 &,- 418 &,- 570 &, 000 &,- 190 \\
\hline & Sig. (2-tailed) &, 754 &, 230 &, 086 & 1,000 &, 599 \\
\hline & $\mathrm{N}$ & 10 & 10 & 10 & 10 & 10 \\
\hline \multirow{3}{*}{ HR Index } & SCC &,- 588 &, $745^{\star}$ & 345 &, 061 &,- 442 \\
\hline & Sig. (2-tailed) &, 074 &, 013 &, 328 &, 868 & ,200 \\
\hline & $\mathrm{N}$ & 10 & 10 & 10 & 10 & 10 \\
\hline \multirow{3}{*}{ Assets 10/09 } & SCC & &,- 479 &,- 042 &, 067 & 455 \\
\hline & Sig. (2-tailed) & &, 162 & ,907 &, 854 &, 187 \\
\hline & $\mathrm{N}$ & & 10 & 10 & 10 & 10 \\
\hline \multirow{3}{*}{ Assets 11/10 } & SCC & & & ,491 & ,267 &,- 188 \\
\hline & Sig. (2-tailed) & & &, 150 &, 455 & ,603 \\
\hline & $\mathrm{N}$ & & & 10 & 10 & 10 \\
\hline \multirow{3}{*}{ ROA 10/09 } & SCC & & & &, 511 & 479 \\
\hline & Sig. (2-tailed) & & & &, 132 &, 162 \\
\hline & $\mathrm{N}$ & & & & 10 & 10 \\
\hline \multirow{3}{*}{ Profit 2010} & SCC & & & & &, $7^{2} 3^{*}$ \\
\hline & Sig. (2-tailed) & & & & & ,018 \\
\hline & $\mathrm{N}$ & & & & & 10 \\
\hline
\end{tabular}

Source: Authors calculation according to Zubović et al., 2012.

More important are correlations 1 and 2. At the same time the change in assets' value in 2010 over 2009 was negatively correlated with the quality of HR department in 2011 . This means that firms that have achieved growth in asset values tend to reduce the quality of HR 
department in the next fiscal year. The explanation may be the fact that firms which have in one fiscal year allocated significant resources to increase their assets sought the reduction of investments that should be aimed at increasing the quality of HR services. However the correlation becomes positive when comparing results to the next fiscal year. This means that there is a significant impact of improved quality of HR department to growth in company assets. Another two components of the HR Index are positively correlated to assets value in the next year.

Therefore it is not surprise to see that the HR Index is positively correlated to change in assets value in the next year. Most significantly, this study proved there is no correlation between business performance in 2010/2009 and the level of HR Index in 2011, confirming hypothesis $\mathrm{H}_{2}$ and rejecting the hypothesis $\mathrm{H}_{3}$. In this way we have confirmed that planned strategic investments in human resources and policies of human resources developed training are not result of good business results in previous years, and that improved quality of the components creating HR Index will result in better business performance.

At the end by using results from correlation analysis it is possible to conduct two regression analyses. In the first one we shall use three variables (Training policy, Training needs and Quality of HR department) which have shown a significant positive correlation with the change in Assets value 2011/10. Three variables are used as predictors and change in assets is used as a dependent variable. Results are shown in Tables 7 and 8.

Table 7. Model Summary

\begin{tabular}{|c|r|r|r|r|}
\hline Model & R & R Square & Adjusted R Square & Std. Error of the Estimate \\
\hline 1 &, $851^{\text {a }}$ &, 725 &, 587 & 23,99138 \\
\hline \multicolumn{7}{|l|}{ a. Predictors: (Constant), Quality of HR Dept, Training policy, Training needs } \\
\hline
\end{tabular}

Source: Authors calculation according to Zubović et al., 2012.

Table 8. Regression Coefficients ${ }^{\text {a }}$

\begin{tabular}{|c|c|c|c|c|c|c|}
\hline & \multirow[t]{2}{*}{ Model } & \multicolumn{2}{|c|}{$\begin{array}{l}\text { Unstandardized } \\
\text { Coefficients }\end{array}$} & \multirow{2}{*}{$\begin{array}{c}\begin{array}{c}\text { Standardized } \\
\text { Coefficients }\end{array} \\
\text { Beta } \\
\end{array}$} & \multirow[t]{2}{*}{ t } & \multirow[t]{2}{*}{ Sig. } \\
\hline & & B & Std. Error & & & \\
\hline \multirow{4}{*}{1} & (Constant) & $-18,353$ & 13,049 & & $-1,406$ & ,209 \\
\hline & Training policy & 11,010 & 17,795 &, 273 &, 619 &, 559 \\
\hline & Training needs & 23,491 & 16,690 &, 728 & 1,407 & ,209 \\
\hline & Quality of HR Dept. & $-2,827$ & 11,902 &,- 130 &,- 238 & 820 \\
\hline
\end{tabular}

Source: Authors calculation according to Zubović et al., 2012.

Despite the fact that R2 value is very high, regression should not be accepted since the significance (Table 8) is not acceptable. For that reason the second regression is conducted by using only the HR Index as a predictor with Change in assets remaining the dependent variable (Tables 9 and 10). 
Table 9. Model Summary

\begin{tabular}{|l|r|r|r|r|}
\hline Model & R & R Square & Adjusted R Square & Std. Error of the Estimate \\
\hline 1 &, $815^{\text {a }}$ &, 665 &, 623 & 22,93763 \\
\hline \multicolumn{2}{|l}{ a. Predictors: (Constant), HR Index } \\
\hline
\end{tabular}

Source: Authors calculation according to Zubović et al., 2012.

Table 10. - Regression Coefficients ${ }^{\text {a }}$

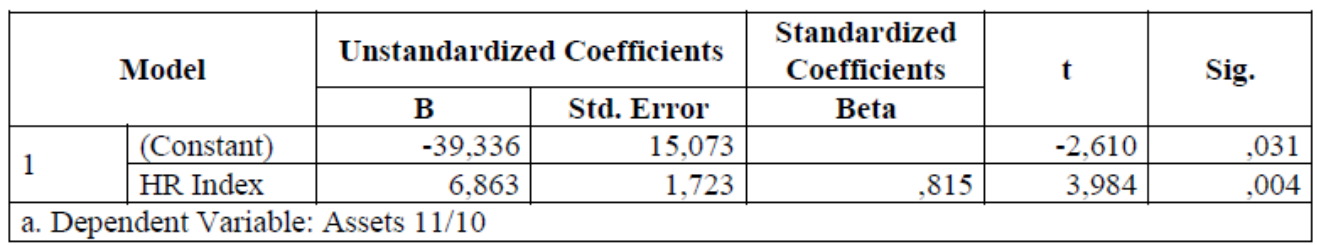

Source: Authors calculation according to Zubović et al., 2012.

Table 11. - Anova test ${ }^{\mathrm{a}}$

\begin{tabular}{|l|l|r|r|r|r|r|}
\hline \multicolumn{2}{|c|}{ Model } & \multicolumn{1}{c|}{$\begin{array}{c}\text { Sum of } \\
\text { Squares }\end{array}$} & df & Mean Square & F & Sig. \\
\hline \multirow{3}{*}{1} & Regression & .835 & 1 & .835 & 15.869 & $.004^{\mathrm{b}}$ \\
\cline { 2 - 7 } & Residual & .421 & 8 & .053 & & \\
\cline { 2 - 7 } & Total & 1.256 & 9 & & & \\
\hline
\end{tabular}

Source: Authors calculation according to Zubović et al., 2012.

In order to test significance of overall regression, we consider relevant $F$ test (testing the null that all regression coefficients are equal to zero vs. alternative that at least one is different than zero). It is lower than standard level of 5\% level of significance, confirming that explanatory power of overall regression is significant (Table 11).

From the table 9 we may see that the value of $\mathrm{R}^{2}$ is at high level confirming that $\mathrm{HR}$ Index may explain $66.5 \%$ of the variance of change in assets value in the following year. In table 10 we may observe that coefficients are statistically significant and therefore it is possible to construct regression formula which tells us that each point change in HRI value would lead to $6.8 \%$ increase in assets value of the company in the following year, as:

$$
\text { As }+1=-39,36 \%+6,863 \% * H R I
$$

Where the following represent:

As+1-Change in Assets value in the following year

HRI- HR Index

In this way we have shown there is a need for creation of an index instead of using individual variables to predict changes in most important business results which is the assets value of the company. 


\section{Conclusions}

Main goal of the paper which was to confirm that sustainability in business can be achieved by improving quality of human resources and its organization in the company has been tested in meat processing industry in Serbia. The initial assumption tested was that if any correlation exists between business results and the level of human capital, positive business result does not tend to increase the level of HR Index but quite the opposite. The research, which tested results in companies that create over $20 \%$ of the assets of the whole sector, has shown that the level of established HR Index, being researched for years by several authors and, adapted to the environment of the economy without the continuous measurement and evaluation of investments in human resources, is not a consequence of good business results. We have demonstrated that the relationship may only be one-way, which means that growth of HR Index does not result from an increase in assets (and other business indicators). However, the correlation proven may be present only in the direction of HRI towards the business results. Therefore, it has been confirmed that in spite of inadequate levels of measurement data on human resources investment, with the help of research conducted worldwide on the basis of econometric models, it is possible to apply this kind of research that directly connect basic research with practical indicators of the economy. The results of this study should be used for further research to be conducted in other business sectors and in different countries of the Western Balkans and beyond.

Shortcomings in this study may exist due to small total number of employees in the MPI sector of only around 12,000 employees according to SBRS data. Moreover it is possible that some companies are unintentionally omitted from the research due to the classification methodology, since they might predominantly operate in one but statistically belong to other sector.

\section{Annex}

Table 12. Macroeconomic data from the meat processing industry in Serbia and microeconomic data on research sample companies

\begin{tabular}{|l|r|r|r|r|r|r|r|r|r|r|}
\hline \multicolumn{1}{|c|}{$\begin{array}{c}\text { SIC07 } \\
\text { classification } \\
\text { of economic } \\
\text { activities }\end{array}$} & \multicolumn{2}{|c|}{$\begin{array}{c}\text { Number of } \\
\text { companies }\end{array}$} & \multicolumn{2}{c|}{ Employees } & \multicolumn{2}{c|}{$\begin{array}{c}\text { Assets } \\
\text { (RSD mil.) }\end{array}$} & \multicolumn{2}{c|}{$\begin{array}{c}\text { Turnover } \\
\text { (RSD mil.) }\end{array}$} & \multicolumn{2}{c|}{$\begin{array}{c}\text { Profit/Loss } \\
\text { (RSD mil.) }\end{array}$} \\
\cline { 2 - 12 } & 2009. & 2010. & 2009. & 2010. & 2009. & 2010. & 2009. & 2010. & 2009. & 2010. \\
\hline $\begin{array}{l}\text { Processing } \\
\text { and } \\
\text { preserving of } \\
\text { meat }\end{array}$ & 231 & 240 & 8,512 & 8,300 & 46,498 & 53,151 & 44,151 & 42,987 & -355 & -471 \\
\hline $\begin{array}{l}\text { Processing } \\
\text { and } \\
\text { preserving of } \\
\text { poultry meat }\end{array}$ & 39 & 34 & 692 & 783 & 9,935 & 5,967 & 2,772 & 3,550 & -363 & -233 \\
\hline $\begin{array}{l}\text { Production } \\
\text { of meat and } \\
\text { poultry meat } \\
\text { products }\end{array}$ & 145 & 152 & 2,286 & 3,195 & 11,875 & 14,904 & 12,950 & 13,498 & -7 & -365 \\
\hline Industry Total & 415 & 426 & 11,490 & 12,278 & 68,308 & 74,022 & 59,873 & 60,036 & -725 & $-1,070$ \\
\hline
\end{tabular}




\begin{tabular}{|l|r|r|r|r|r|r|r|r|r|r|}
\hline \multicolumn{1}{c|}{$\begin{array}{c}\text { SIC07 } \\
\text { classification } \\
\text { of economic } \\
\text { activities }\end{array}$} & \multicolumn{2}{|c|}{$\begin{array}{c}\text { Number of } \\
\text { companies }\end{array}$} & \multicolumn{2}{|c|}{ Employees } & \multicolumn{2}{c|}{$\begin{array}{c}\text { Assets } \\
\text { (RSD mil.) }\end{array}$} & \multicolumn{2}{c|}{$\begin{array}{c}\text { Turnover } \\
\text { (RSD mil.) }\end{array}$} & \multicolumn{2}{c|}{$\begin{array}{c}\text { Profit/Loss } \\
\text { (RSD mil.) }\end{array}$} \\
\cline { 2 - 12 } & 2009. & 2010. & 2009. & 2010. & 2009. & 2010. & 2009. & 2010. & 2009. & 2010. \\
\hline $\begin{array}{l}\text { Research } \\
\text { Sample }\end{array}$ & 10 & 10 & 2,439 & 2,531 & 10,931 & 15,920 & 12,103 & 14,295 & 124 & 93 \\
\hline $\begin{array}{l}\text { Sample } \\
\text { share in } \\
\text { population } \\
\text { (\%) }\end{array}$ & & & $21.23 \%$ & $20.61 \%$ & $16.00 \%$ & $21.51 \%$ & $20.21 \%$ & $23.81 \%$ & & \\
\hline
\end{tabular}

Source: SBRS, 2012.

\section{References}

1. Awang, A. H., Ismail, R., Noor, Z. M. (2010): Training Impact on Employee's Job Performance: A Self Evaluation, Ekonomska istraživanja, vol. 23, no. 4, pp. 78-90.

2. Bassi, L., McMurrer, D. P. (199): Indicators of Human Capital Investment and Outcomes from the American society for training \& development, in: Measuring and Reporting Intellectual Capital: Experience, Issues, and Prospects, Amsterdam, June 1999, pp. 1-10, available at: www.oecd.org/dataoecd/61/44/1947815.pdf, accessed at: 12 March 2012.

3. Bassi, L., McMurrrer, D. (2007): Maximising your Return on People, Harvard Business Review, vol. 85, no. 3, pp. 115-123.

4. Birch, K., Levidow, L., Papaioannou, T. (2010): Sustainable Capital? The Neoliberalization of Nature and Knowledge in the European "Knowledge-based Bio-economy", Sustainability, no. 2, pp. 2898-2918.

5. Chasovskaya, E. (2010): Human Resources Analysis in International Business, Information Technologies, Management and Society, vol. 3, no. 1, pp. 112-114.

6. Cranet (2008): The list of researches conducted using Cranet questionnaire, available at: www.cranet.org/downloads/EnglishPost2000.doc, accessed at: 14 October 2011.

7. Darwish, T., Singh, S., Mohamed, A. (2013): The role of strategic HR practices in organisational effectiveness: an empirical investigation in the country of Jordan, International Journal of Human Resource Management, (serial online), vol. 24, no. 17 , pp. 3343-3362.

8. Dearden, L., McIntosh, S., Myck, M., Vignoles, A. (2002): The returns to academic and vocational qualifications in Britain, Bulletin of economic research, vol. 54, no. 3, pp. 249274.

9. Denisova Schmidt, E. (2011): Human Resource Management in Russia: Some Unwritten Rules, WU Online Papers in IBC, series one: Intercultural Communication and Language Learning, paper 8, Department für Fremdsprachliche Wirtschaftskommunikation, WU Vienna University of Economics and Business, Vienna, pp. 1-12, available at: http://epub. wu.ac.at/3153/1/08-denisova endversion.pdf, accessed at: 10 June 2014.

10. Done, I., Domazet, I. (2011): Improving the quality of human resources by implementation of internal marketing, in: Andrei et al. (Edt.), The role of labour markets and human capital 
in the unstable environment, KARTA GRAPHIC Publishing House, Ploiesti, Romania, pp. 47-75.

11. Ene, C. (2012): Consumer protection in Bulgaria: EU challenges, Economics of Agriculture, vol. 59, no. 2, pp. 253-265.

12. De la Fuente, A., Ciccone, A. (2002): Human capital in a global and knowledge-based economy, Final Report, European Commission, Directorate General for Employment and Social Affairs, Unit A.1, Brussels, Belgium, available at: www.antoniociccone.eu/wpcontent/uploads/2007/07/humancapitalpolicy.pdf

13. Government of Serbia (2008): National Strategy of Sustainable Development of Republic of Serbia, Official Gazzete of the Republic of Serbia, no. 57/08.

14. Greer, C. R. (2006): Strategic Human Resource Management, $2^{\text {nd }}$ edition, Dorling Kindersley (India) Pvt Ltd, India.

15. Griliches, Z. (1997): Education, human capital and growth: a personal perspective, Journal of Labor Economics, vol. 15, no. 1- Part 2, pp. S330-S344.

16. Hanson, B., Johanson, U., Leitner, K. H. (2004): The impact of human capital and human capital investments on company performance - Evidence from literature and European survey results, in: Descy, P., Tessaring, M. (Eds.) Impact of education and training, Cedefop Reference series, 54, Office for Official Publications of the European Communities, Luxembourg, pp. 262-319.

17. Katou, A., Budhwar, P. (2012): The Link between HR Practices, Psychological Contract Fulfilment, and Organizational Performance: The Case of the Greek Service Sector, Thunderbird International Business Review, (serial online), November 2012, vol. 54, no. 6, pp. 793-809.

18. Kwon, K., Rupp, D. E. (2013): High-performer turnover and firm performance: The moderating role of human capital investment and firm reputation, Journal of Organizational Behavior, vol. 34, no. 1, pp. 129-150.

19. Montoya, J. A. (2013): The Value of Human Capital in Colombia, 2001-2009: An Estimate Based on the Lifetime Income Approach, October 9, available at: http://papers.ssrn.com/ sol3/papers.cfm?abstract id $=2338318$

20. Mubarik, M. S., Govindaraju, V. C., Devadason, E. S. (2014): Proposed Framework for Assessing Human Capital: Derivation of the Human Capital Index and its Application, May 5, pp. 1-28, available at: http://papers.ssrn.com/sol3/papers.cfm?abstract $\underline{\mathrm{id}=2433166}$

21. Nikolić, I., Zubović, J. (2013): Structural changes in Serbian industry during transition, Industrija, vol. 41, no. 2, pp. 67-79.

22. Serbian business registers agency (SBRS), Data on participation of meat processing industry in Serbian economy, Materials received by email on request to SBRS, sent in January 2012.

23. Stacey, R. D. (2001): Complex responsive processes in organizations: Learning and knowledge creation, London: Routledge, UK. 
24. Subić, J., Jeločnik, M., Jovanović, M. (2013): Evaluation of Social Sustainability of Agriculture within the Carpathians in the Republic of Serbia, Scientific Papers. Series Management, Economic Engineering in Agriculture \& Rural Development, vol. 13, no. 2, pp. 411-415.

25. Theriou, G., Chatzoglou, P. (2014): The impact of best HRM practices on performance - identifying enabling factors, Employee Relations, (serial online), September 2014, vol. 36 , no. 5, pp. 535-561.

26. Tkachenko, O., Ardichvili, A. (2013): Human Capital Development in Central and Eastern Europe: an Analysis of Trends and Challenges Facing Hungary, the Czech Republic, Slovenia, Estonia, and the Russian Federation, published on UFHRD Conference, Brighton, UK, available at: www.ufhrd.co.uk/wordpress/wp-content/uploads/2013/09/TkachenkoArdichvili-working-paper.pdf, accessed at: 10 June 2014.

27.Watson Wyatt Worldwide Research (2012): Human capital index: Linking human capital and shareholder value, Watson Wyatt Worldwide Research, Washington DC, USA, pp. 1-12.

28.Zubović, J., Domazet, I. (2013): Effectiveness of government interventions at labour markets: the case of women and youth in Serbia, Actual Problems of Economics, vol. 13, no. 139 , pp. 302-313.

29.Zubović, J., Domazet, I., Bradić Martinović, A. (2008): Foreign investments to developing countries 'food industry: does it improve competitiveness, trade and $R \& D$, ин proceedings State, Possibilities and Perspectives of Rural Development on Area of Huge Open-pit Minings, Institute for Agricultural Economics, Belgrade, pp. 79-85.

30.Zubović, J., Jeločnik, M., Subić, J. (2012): A survey conducted in meat processing industry companies in Serbia 2011-2012, unpublished research material, internal documentation (questionaires), IAE Belgrade.

31.Zubović, J., Jeločnik, M., Subić, J. (2011): The Analysis of HR Index in Serbian Financial Industry, Industrija, vol. 39, no. 1, pp. 227-242. 


\title{
KAKO LJUDSKI RESURSI UTIČU NA ODŽIVOST POSLOVANJA? MODELIRANJE, TESTIRANJE I KORELACIJA HR INDEKSA I POSLOVNIH REZULTATA
}

\author{
Jovan Zubovič́, Marko Jeločnik, Jonel Subić7
}

\begin{abstract}
U ovom radu autori analiziraju uticaj kompozitnog indeksa ljudskih resursa na održiv rast u pojedinim granama privrede u zemljiu tranziciji. Održivost nacionalne privrede postaje sve više zavisna od ekonomije znanja. Ekonomija znanja je implementirana u strategije održivog razvoja u velikom bru evropskih zemalja. Ekonomija znanja je uglavnom zasnovana na ljudskim resursima I načinu kako se oni organizuju stilu rukovođenja na konkurentnom tržištu. Kako bi se potvrdio značaj indeksa ljudski resursa (HRI)u ovom radu su testirani dobijeni razultati kroz modeliranje, merenje I korelaciju dobijenog HR indeksa I poslovnih rezultata na mikro nivou. Analiza je sprovedena u sektoru mesno-prerađivačke industriji Srbije. Rezultati su takođe upoređeni sa rezultatima dobijenim u istraživanju $u$ finansijkom sektoru. Potvrđeno je da model može da se primeni u zemljama u kojima ne postoje zvanični statistički podaci o nivou ulaganja u ljudske resurse. Fokus istraživanja je bio da se utvrdi smer korelacije koja postoji, odnosno da se potvrdi da ulaganje u ljudske resurse void ka poboljšanju poslovnih rezultata. Time je potvrđeno da se ovaj model može koristiti u svim sektorima privrede. Rezultati su potvrdili da je u privredi Srbije moguće u uslovima recesije ostvariti povoljne poslovne rezultate kroz investicije u ljudske resurse I da kompanije koje podižu svoj HRI kao rezultat ostvaruju natprosečne poslovne rezultate I održivi rast.
\end{abstract}

Ključne reči: Investicije, HR indeks, Korelacija, Modeliranje.

5 Dr Jovan Zubović, naučni saradnik, Institut ekonomskih nauka, Zmaj Jovina 12, 11000 Beograd, Srbija, Telefon: +381 112623 055, E-mail: jovan.zubovic@,ien.bg.ac.rs

6 Marko Jeločnik, M.A., istraživač saradnik, Institut za ekonomiku poljoprivrede, Volgina 15, 11060 Beograd, Srbija, Telefon: +381 116972 852, E-mail: marko_j@iep.bg.ac.rs

7 Dr Jonel Subić, viši naučni saradnik, Institut za ekonomiku poljoprivrede, Volgina 15, 11060 Beograd, Srbija, Telefon: +381 116972 858, E-mail: jonel_s@iep.bg.ac.rs 